\title{
A PHYSICAL HYDRAULIC MODEL TEST TO SOLVE THE PROBLEM ON SPILLWAY DAM
}

\author{
*Linda Prasetyorini ${ }^{1}$, Nadjadji Anwar ${ }^{2}$ and Wasis Wardoyo ${ }^{3}$ \\ 1,2,3 Faculty of Civil Engineering, Environmental and Geo Engineering, Sepuluh Nopember Institute of \\ Technology, Indonesia; ${ }^{1}$ Civil Engineering, University of Brawijaya, Indonesia
}

*Corresponding Author, Received: 18 Dec. 2019, Revised: 13 March 2020, Accepted: 10 April 2020

\begin{abstract}
This research studies about the hydraulic performance and and the problem solving alternatives of spillway design at Fila Tukutaha Dam, Alor District Indonesia. Flow water passing over the spillway of a dam typically has a large amount of energy, must be dissipated safely before the floodwaters rejoin to the natural river system. Therefore, energy dissipation takes place at the downstream end of the chuteway. The stilling basin at the end of the chute way is commonly used to dissipate energy from the spillway and slow the water velocity to protect the downstream river channel from erosion and damage. The methodology of experiment consists of physical modeling in the Hydraulic and Coastal Engineering Laboratory of Civil Departement, Sepuluh Nopember Institute of Technology. The discharge design was analyzed by hydrological routing formula over the spillway. The methods include Bernoulli's formula equation for the steeply sloped channel, the standard step formula for calculating the energy equation on the transition channel, and the USBR type 2 for designing the stilling basin. From the experimental result, cross-flow was reduced by adding the hexagonal baffle block on the transition channel, and the effectiveness of stilling basin was occurred by placing the abrupt rise in the downstream area.
\end{abstract}

Keywords: Hydraulic, Stilling Basin, Effectiveness, Abrupt Rise

\section{INTRODUCTION}

The problems was faced during the design of spillway are the safety transport of large amount of waters from reservoir into the intake and energy dissipation [1]. The energy dissipation on the downstream area commonly used to dissipate energy from spillway and slow the water velocity to protect the downstream river channel from erosion and damage. Kinetic energy of water flowing through the spillway must be dissipated to prevent scouring of downstream riverbed and failure of downstream structures, so, the basin should be designed to dissipate the energy kinetik of water through formation of a hydraulic jump. Hydraulics physical model test is needed to analyze an to evaluate the flow condition from the spillway, stilling basin, until the escape channel on the downstream area. Therefore, the safety design is hoped to obtain, remembering that the dam construction is as an essential building and has a high risk in financial as well as the social aspect [2].

\section{METHOD}

Fila Tukutaha Dam is located in the Alor District, Nusa Tenggara Timur Province, Indonesia. The physical model test was carried out at the Hydraulic and Coastal Engineering Laboratory of
Civil Departement, Sepuluh Nopember Institute of Technology.

\subsection{Scale Model}

The aim of model test is to evaluate and to achieve the perfect, safe and optimum hydraulic design of the spillway dam. The test has used a scale of the model and based on some condition as follow:

1) The aim of the test and the accuracy that is hoped, 2) The facility is available in the laboratory as well as possible time and cost. However, the permissibility of minimum scale is due to the minimum water depth over the crest spillway, such as $1.69 \mathrm{~m}$ (based on the analysis of spillway design with $Q_{5}$ year $=152.27 \mathrm{~m}^{3} / \mathrm{s}$ ). The formula as shown below [3] :

$$
\begin{aligned}
& \frac{\Delta \mathbf{q}}{\mathbf{q}}=1-\left\{\frac{\mathbf{H}_{\mathbf{e}}}{\mathbf{H}}\right\}^{\frac{3}{2}} \\
& 5 \%=1-\left\{\frac{\mathrm{H}-0.457}{\mathrm{H}}\right\}^{3 / 2}
\end{aligned}
$$

$\mathrm{H}=13.494 \mathrm{~mm}$

Minimum a scale of the model is $1: 125.250$ as the formula below

$\mathrm{Lr}=\frac{13.494}{1690}=\frac{1}{125.250}$ 
The undistorted scale 1:50 is used because of the condition of the laboratory and capacity of diesel pump laboratory.

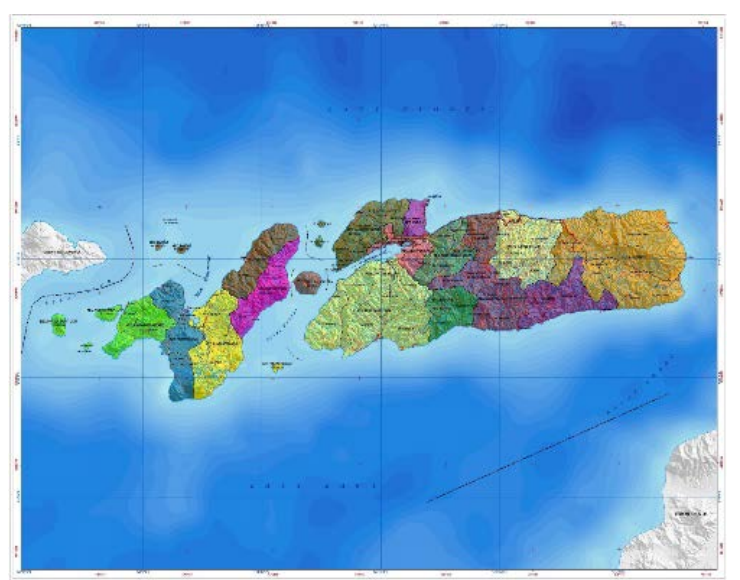

Fig. 1. Map of study location

Fila Tukutaha spillway dam consists of a $123.08 \mathrm{~m}$ tunnel with $5.50 \mathrm{~m}$ diameter, which is continued with $98 \mathrm{~m}$ open channel. Cuteway channel with 1:3 slope and $31.37 \mathrm{~m}$ length was designed to delivered water from open channels into stilling basin area, as detail shown on the table 1 below.

Table 1. Dimension of spillway

\begin{tabular}{|c|c|c|}
\hline Description & $\begin{array}{c}\text { Prototype } \\
(\mathrm{m})\end{array}$ & $\begin{array}{c}\text { Model } \\
(\mathrm{cm})\end{array}$ \\
\hline \multicolumn{3}{|l|}{ Spillway } \\
\hline Type of spillway & $\begin{array}{c}\text { Ogee with } \\
\text { tunnel }\end{array}$ & \\
\hline Crest of Weir & +67.00 & +67.00 \\
\hline Upstream approach channel & +64.00 & +64.00 \\
\hline Width & 35.00 & 70.00 \\
\hline Slope & $1: 10$ & $1: 10$ \\
\hline \multicolumn{3}{|l|}{ Tunnel } \\
\hline Dimension & 5.50 & 11.00 \\
\hline Elevation & +63.50 & +63.50 \\
\hline Length & 123.08 & 246.16 \\
\hline \multicolumn{3}{|l|}{ Transition channel } \\
\hline Elevation & +43.87 & +43.87 \\
\hline Length & 98.00 & 196.00 \\
\hline Slope & $1: 500$ & $1: 500$ \\
\hline \multirow[t]{2}{*}{ Width } & $\begin{array}{c}\text { upstream } \\
15.50\end{array}$ & 31.00 \\
\hline & $\begin{array}{c}\text { downstream } \\
18.00\end{array}$ & 36.00 \\
\hline \multicolumn{3}{|l|}{ Cuteway } \\
\hline Length & 31.37 & 62.74 \\
\hline Width & 18.00 & 36.00 \\
\hline
\end{tabular}

\begin{tabular}{lcc}
\hline Slope & $1: 3$ & $1: 3$ \\
\hline Stilling Basin & & \\
\hline Elevation & +28.00 & +28.00 \\
\hline Length & 29.00 & 58.00 \\
\hline Width & 18.00 & 36.00 \\
\hline Outlet Channel & & \\
\hline Elevation & +32.00 & +32.01 \\
\hline Length & 230.00 & 460.00 \\
\hline Width & 18.00 & 36.00 \\
\hline
\end{tabular}

\subsection{Discharge coefficient of Spillway}

To calculate the discharge over the spillway is used the formula as follow [4] :

$$
\mathrm{Q}=\mathrm{C} . \mathrm{L} \cdot \mathrm{H}^{3 / 2}
$$

Where : $\mathrm{C}=$ the overflow discharge coefficient of standar weir type, $\mathrm{L}=$ the length of spillway weir (m), $\mathrm{H}=$ the energy of water above the weir (m). The overflow discharge coefficient for standard type of weir can shown by the formula of Iwasaki as follow [5] :

$$
\begin{aligned}
& \mathrm{Cd}=2,200-0.0416\left(\frac{\mathrm{H}_{\mathrm{d}}}{\mathrm{W}}\right) \\
& \mathrm{C}=1.60 \frac{1+2 \propto\left(\frac{\mathrm{h}}{\mathrm{H}_{\mathrm{d}}}\right)}{1+\propto\left(\frac{\mathrm{h}}{\mathrm{H}_{\mathrm{d}}}\right)}
\end{aligned}
$$

Where : $\mathrm{C}=$ the overflow discharge coefficient, $\mathrm{Cd}$ = coefficient of overflow discharge when $\mathrm{h}=\mathrm{H}_{\mathrm{d}}$, $\mathrm{H}_{\mathrm{d}}=$ water depth over the weir (m), and $\mathrm{W}=$ height of weir (m)

\subsection{Transition Channel}

The formula for hydraulics analysis condition of the transition channel due to the Bernoulli formula as follow [6]:

$$
\mathrm{d}_{\mathrm{e}}+\frac{\mathrm{V}_{\mathrm{e}}^{2}}{2 \mathrm{~g}}=\mathrm{d}_{\mathrm{c}}+\frac{\mathrm{V}_{\mathrm{c}}^{2}}{2 \mathrm{~g}}+\frac{\mathrm{K}_{\left(\mathrm{C}_{\mathrm{c}}^{2}-\mathrm{V}_{\mathrm{e}}\right)^{2}}}{2 \mathrm{~g}}+\mathrm{h}_{\mathrm{m}}
$$

Where: $\mathrm{d}_{\mathrm{e}}=$ flow depth into transition channel, $\mathrm{v}_{\mathrm{e}}$ = flow velocity into transition channel, $\mathrm{d}_{\mathrm{c}}=$ critical depth in the transition channel end, $\mathrm{v}_{\mathrm{c}}=$ critical flow velocity in the upstream end of transition channel, $\mathrm{K}=$ coefficient of pressure head loss, $\mathrm{g}=$ acceleration of gravity, $\mathrm{h}_{\mathrm{m}}=$ total loss of friction coefficient

\subsection{Stilling Basin}

Before the water from the spillway flows back to the river, it has to be slow down, and it is changed as the subcritical condition, so there does not happen the scouring, which endangers river geometric on the bed and edge river [7].

The stilling basin is a structure that will dissipate energy from a high-velocity spillway chute. A hydraulic jump is a sudden phenomenon 
transition from a supercritical open channel condition to a subcritical flow regime. Hydraulic jump's performance must be in the range of the stilling basin's length.

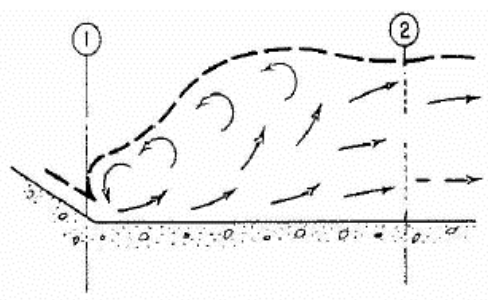

Fig. 2. Performance of hydraulic jump on the horizontal floor

The continuity and momentum principle for a horizontal rectangular channel well-known as the Belanger Equation as shown on the formula below [8].

$$
\frac{\mathrm{d}_{2}}{\mathrm{~d}_{1}}=\frac{1}{2}\left(\sqrt{1+8 \mathrm{Fr} 1^{2}}-1\right)
$$

Where : $\mathrm{d}_{1}=$ initial depth, $\mathrm{d}_{2}=$ conjugate depth, $\mathrm{Fr}=$ Froude number

The type 2 basin uses chute blocks and a dentated sill for shortening the jump length and for dissipating the high-velocity flow within the shortened basin length [9]. This basin was dissipated the turbulence of the jump phenomena for its effectiveness. The design criteria of the stilling basins' spillway are based on Froude Number (Fr) and discharge per width of the channel (q). Standard stilling basin designs, such as U.S Berau Reclamation's Type 2 stilling basin, were developed to provide appropriate energy dissipation for these smooth spillways.

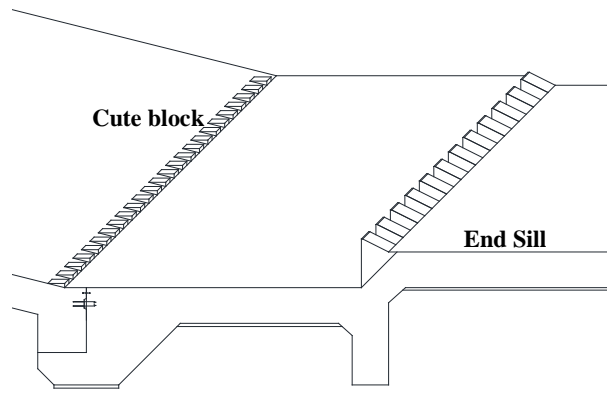

Fig. 3. USBR type 2 stilling basin's design

\subsection{Reynold Number}

The Reynold Number (Re) is an essential dimensionless quantity in fluid mechanics used to help predict flow patterns to represent whether the fluid flow in a structure is laminer or turbulent. At low Reynolds numbers, flows to be dominated by laminar flow. In contrast, at high Reynolds numbers, turbulence results from differences in the fluid's speed and direction, which may sometimes be making cross flow, cavitation, and eddy current phenomena.

The Reynolds number formula is expressed by

$$
\mathrm{Re}=\frac{\rho \cdot v \cdot L}{\mu}
$$

Where $: \rho=$ density of the fluid, $v=$ velocity of the fluid, $\mu=$ viscosity of fluid, and $L=$ length or diameter of the fluid.

The Kind of flow is based on the value of Re

If $\operatorname{Re}<2000$, the flow is called Laminar

If $\operatorname{Re}>4000$, the flow is called turbulent

If $2000<\operatorname{Re}<4000$, the flow is called transition.

\section{RESULT AND DISCUSSION}

Experiment were conducted in Hydraulic and Coastal Engineering Laboratory of Civil Departement,Sepuluh Nopember Institute of Technology with Fila Tukutaha Dam's phisycal modelling.

Some characteristic operation conditions from the upstream of the spillway were analyzed in the physical model. The water levels, the mean velocities, and the instantaneous pressures, in various points of the flow, were measured with point gauge, pitot tube, and current meter.

Thompson measurement were used to control discharge capacity over the spillway. Rating curve of discharge on the model is presented in Figure 3 below and were design by Minitab 17 program to calculate normality of data. $\mathrm{C}_{1}$ for Thompson water depth $(\mathrm{cm})$ and $\mathrm{C}_{2}$ for discharge (lt/s). From the result it can be inferred that condition of data for the experimental with $\mathrm{R}^{2}=95,8 \%$.

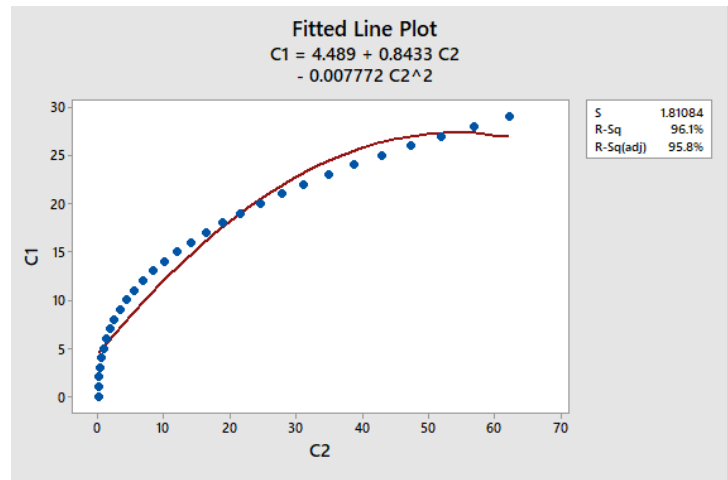

Fig. 4. Rating Curve of Thompson Discharge

The spillway was designed for a 100 years return period flood discharge is $260.59 \mathrm{~m}^{3} / \mathrm{s}$. Based on the analysis of hydrology design, it is made the comparison between the real condition discharge until probability maximum flood (PMF) year return period and model discharge as shown on fig. 5 below. 


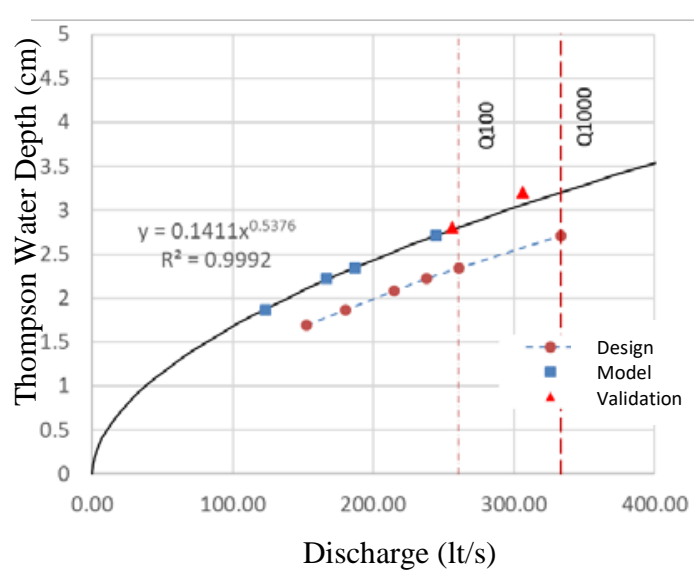

Fig. 4. Validation of Outflow Discharge on Model

Table 2. Water depth over the spillway

\begin{tabular}{|c|c|c|c|c|}
\hline \multirow{2}{*}{ No } & \multirow{2}{*}{$\begin{array}{l}\text { Return } \\
\text { Period } \\
\text { (year) }\end{array}$} & \multirow{2}{*}{$\begin{array}{c}\text { Q } \\
\text { Outflow } \\
\left(\mathrm{m}^{3} / \mathrm{s}\right) \\
\end{array}$} & \multicolumn{2}{|c|}{$\begin{array}{l}\text { Water Depth Over The } \\
\text { Spillway (Hd) }\end{array}$} \\
\hline & & & $\begin{array}{c}\text { Prototype } \\
(\mathrm{m})\end{array}$ & $\begin{array}{c}\text { Model } \\
(\mathrm{m})\end{array}$ \\
\hline 1 & 5 & 152.27 & 1.69 & 1.55 \\
\hline 2 & 10 & 180.09 & 1.87 & 1.70 \\
\hline 3 & 25 & 214.09 & 2.08 & 1.85 \\
\hline 4 & 50 & 237.65 & 2.22 & 2.00 \\
\hline 5 & 100 & 260.59 & 2.34 & 2.20 \\
\hline 6 & 1000 & 333.41 & 2.72 & 2.50 \\
\hline 7 & PMF & 705.25 & 4.24 & 3.80 \\
\hline
\end{tabular}

Table 2 above shows that the similar water depth over the spillway between the USBR formula and the model with a relative error of approximately $8.5 \%$.

Based on $\mathrm{Q}_{100}$ original design, it can be shown that the incoming depth, $\mathrm{h}_{1}=0.78 \mathrm{~m}$, the velocity, $\mathrm{V}_{1}=18.49 \mathrm{~m} / \mathrm{s}$, Incoming Froude number $\mathrm{Fr}=6,67$. The height after the hydraulic jump, $\mathrm{V}_{2}=7.01 \mathrm{~m}$. USBR Type 2 stilling basin with 29 m length was used in the original design with a $\mathrm{Q}_{100}$ discharge design flood. Abrupt rise with slope 2:1 were installed at the end of stilling basin until elevation $+32,00$ (stilling basin elevation is $+28,00$ ).

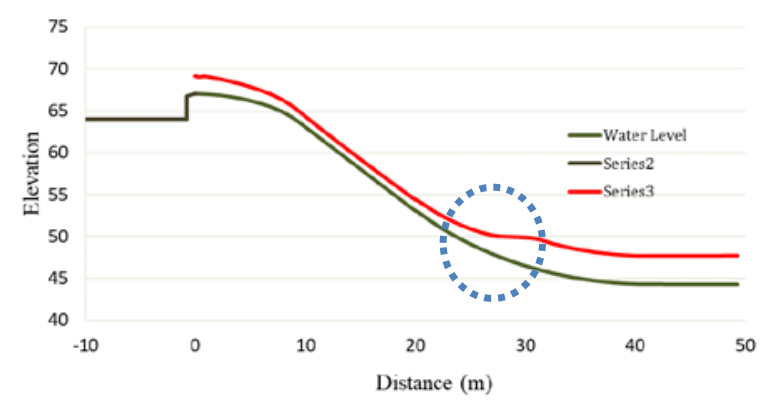

Fig 6. Water lever profile along spillway and tunnel channel
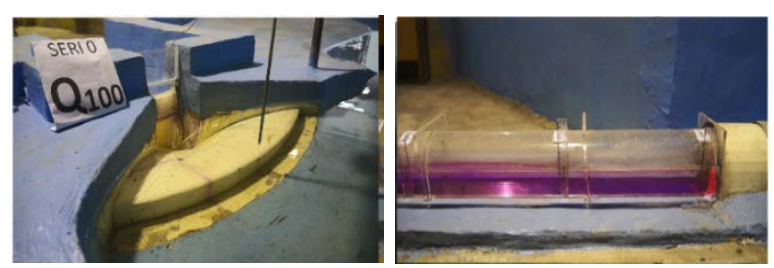

Fig. 7. The flow condition on the spillway and tunnel channel

Based on calculation result and experimental data, the flow condition entrance tunnel has turbulent flow because of Reynold Number more than 4000 with $5.50 \mathrm{~m}$ diameter pipe. It can be inferred that turbulent flow was occurred over along the tunnel as shown on table 3 .

Table 3. Reynold Number in Tunnel Channel

\begin{tabular}{ccccc}
\hline \multirow{2}{*}{ No } & $\begin{array}{c}\text { Return } \\
\text { Period }\end{array}$ & $\begin{array}{c}\mathrm{Q} \\
\text { Outflow }\end{array}$ & $\begin{array}{c}\text { V tunnel } \\
\text { entrance }\end{array}$ & $\begin{array}{c}\text { Reynold } \\
\text { Number }\end{array}$ \\
\cline { 2 - 4 } & (year) & $\left(\mathrm{m}^{3} / \mathrm{s}\right)$ & $(\mathrm{m} / \mathrm{s})$ & \\
\hline 1 & 5 & 152.27 & 6.94 & 4283951 \\
\hline 2 & 10 & 180.09 & 8.21 & 5067901 \\
\hline 3 & 25 & 214.09 & 9.76 & 6024691 \\
\hline 4 & 50 & 237.65 & 10.83 & 6685185 \\
\hline 5 & 100 & 260.59 & 11.88 & 7333333 \\
\hline 6 & 1000 & 333.41 & 12.09 & 7462963 \\
\hline 7 & PMF & 705.25 & 21.94 & 13543210 \\
\hline
\end{tabular}

From the experimental laboratory, it can be shown that a) the spillway design is able to flow the all discharge condition until QPMF and safe against overtopping b) Turbulent flow was happened along the tunnel and making crossflow on the outlet tunnel (transition channel) for the all flood design c) Critical depth $(\mathrm{Fr}=1)$ was not occurred at the start of chuteway as shown on fig. $8 \mathrm{~d}$ ) The stilling basin was not dissipated the energy from chute way because the unstable condition on the upstream area.
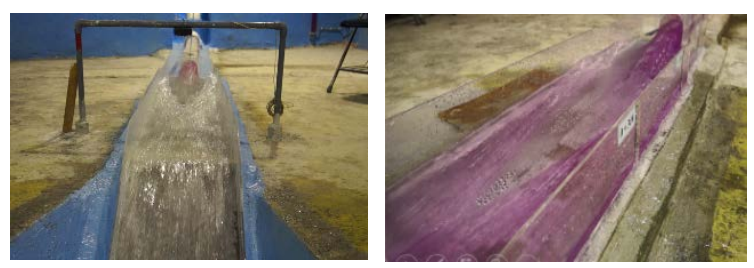

Fig. 8. Cross flow condition on the transition channel 


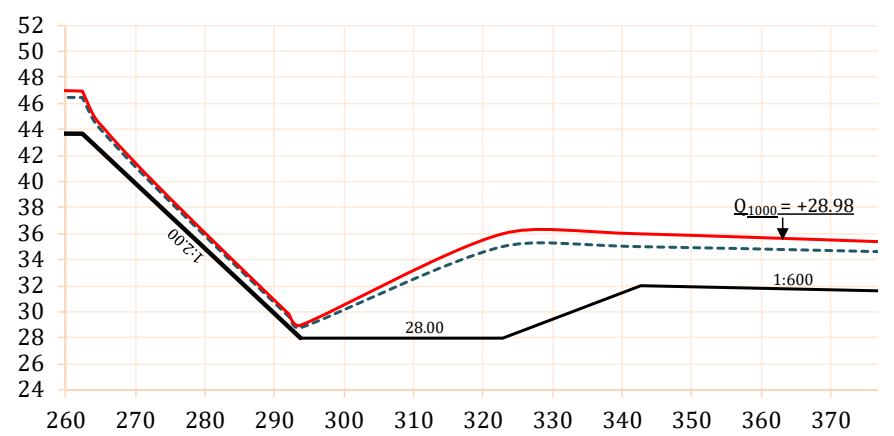

phenomenon is very dangerous, it can destroy the overflow dam as well as the dam itself because this structure is the primary protector of the dam. Fila Tukutaha spillway dam were controlled from the cavitation process at the cute of spillway as shown on table 4 below.

Table 4. Control of cavitation condition

Fig.9. Water lever profile along cute way and stilling basin
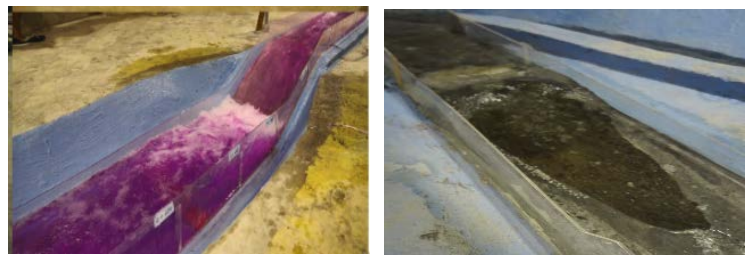

Fig. 10. The flow condition on stilling basin and escape channel

The modified baffle block with $1 \mathrm{~cm}$ length and height hexagonal design (on the model) was placed along the transition channel to reducing the cross-flow effect. Several experiments were carried out in the laboratory by placing various baffle block positions until the best result was obtained. The value of the Froude number presented the excellent condition of the flow at the end of the transition channel (at the beginning of the chuteway channel) equal with one as usually called critical flow. The test result indicates that it has the ability to control rid of the cross-flow on the downstream regulator channel and to be able to dissipate energy on the downstream, as shown in fig. 11.
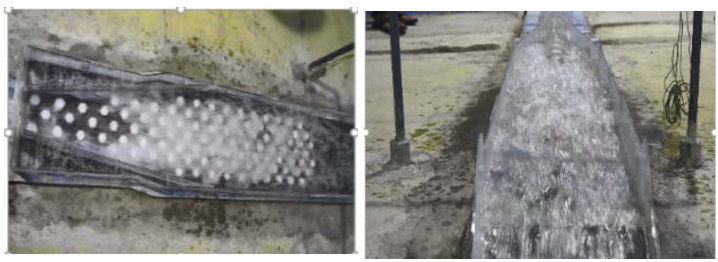

Fig.11. The flow condition of the transsition channel after placing hexagonal baffle block

Cavitation is the process when the local pressure at a point in a flowing water mass is reduced to the vapor pressure of the water. Vapor cavities are formed, and then swept downstream. Cavitation is a common problem in dams, especially in the spillway system. Several conditions at the entrance of weir, when the velocity more than $4 \mathrm{~m} / \mathrm{s}$ and the other at the cute of the spillway. Damage caused by the cavitation

\begin{tabular}{ccccc} 
No & $\begin{array}{c}\mathrm{Q} \\
\text { Outflow }\end{array}$ & $\begin{array}{c}\text { Initial } \\
\text { Depth } \\
\left(\mathrm{d}_{1}\right)\end{array}$ & $\begin{array}{c}\text { Incoming } \\
\text { Velocity } \\
\left(\mathrm{v}_{1}\right)\end{array}$ & Condition \\
\cline { 2 - 4 } & $\left(\mathrm{m}^{3} / \mathrm{s}\right)$ & $(\mathrm{m})$ & $(\mathrm{m} / \mathrm{s})$ & \\
\hline 1 & 152.27 & 0.33 & 25.80 & No Cavitation \\
\hline 2 & 180.09 & 0.39 & 25.91 & No Cavitation \\
\hline 3 & 214.09 & 0.46 & 26.03 & No Cavitation \\
\hline 4 & 237.65 & 0.51 & 26.11 & No Cavitation \\
\hline 5 & 260.59 & 0.55 & 26.19 & No Cavitation \\
\hline 6 & 333.41 & 0.70 & 26.41 & No Cavitation \\
\hline 7 & 705.25 & 1.26 & 31.07 & No Cavitation \\
\hline
\end{tabular}

The effectivity of stilling basin USBR Type 2 was happened with the full $(0,8-1,0 \mathrm{~d} 2)$ conjugate tailwater depth, so that the length of USBR type 2 stilling basin with the abrupt rise on the downstream area was designed because of the lower tailwater depth condition on the downstream area. There is the ideal condition, if $\mathrm{d} 2>$ tailwater depth, it is recommended to use apron protection, modification baffles, and end sill, to create hydraulic jump within the basin.
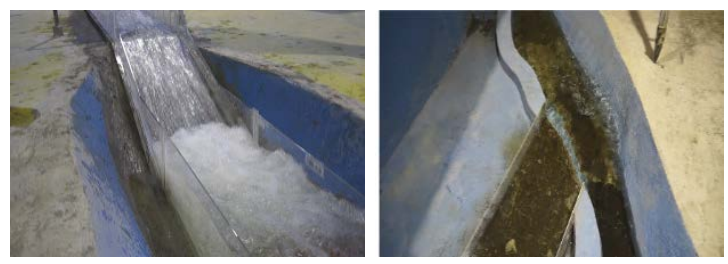

Fig.12. The flow condition of the stilling basin and outlet channel

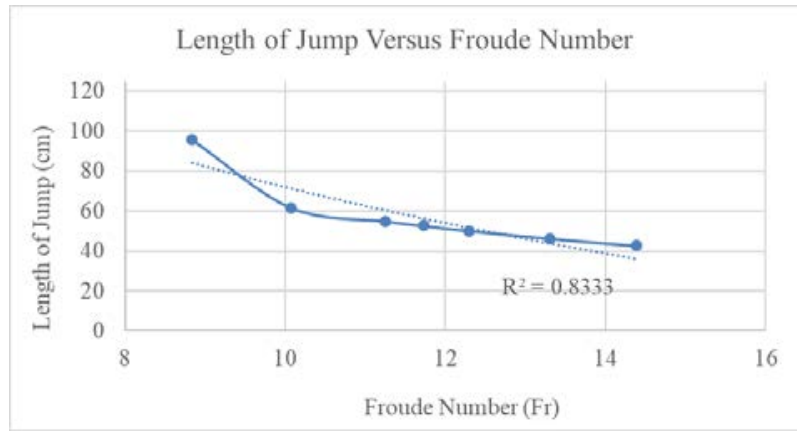

Fig 13. Length of Jump versus Froude Number

Figure 13 above showing The comparison of its relative length of jump with the various discharge 
with Froude Number equations using the experimental data of the Fila Tukutaha spillway model test. The ratio of sequent depth was correctly predicted by Belanger (1838) by using the momentum equation [10]. The increase of sequent depth ratio to showing Froude Number increase as shown as the momentum equation below.

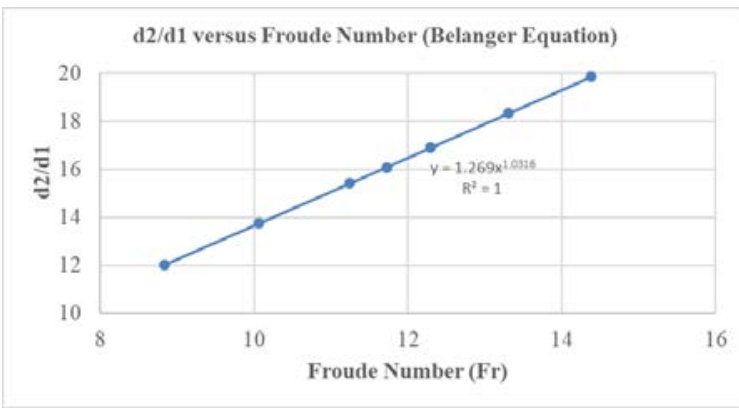

Fig 14. d2/d1 versus Froude Number

The effectivity of stilling basin related with Froude Number. The energy loss is the result of a specific energy calculation upstream of stilling basin minus the specific energy downstream of stilling basin. The percentage of energy loss is the amount of energy loss that can be reduce in the flow, calculated from the energy loss divided by the energy in the upstream of stilling basin then multiplied by $100 \%$.

Table 5. Effectivity of Stilling Basin

\begin{tabular}{|c|c|c|c|c|c|}
\hline \multirow[t]{2}{*}{ No } & $\begin{array}{c}\mathrm{Q} \\
\text { Outflow }\end{array}$ & $\mathrm{E}_{1}$ & $\mathrm{E}_{2}$ & $\Delta \mathrm{E}$ & $\begin{array}{c}\text { Effectivi } \\
\text { ty }\end{array}$ \\
\hline & $\left(\mathrm{m}^{3} / \mathrm{s}\right)$ & & & & (\%) \\
\hline 1 & 152.27 & 34.26 & 6.59 & 27.66 & 80.75 \\
\hline 2 & 180.09 & 34.60 & 7.18 & 27.42 & 79.25 \\
\hline 3 & 214.09 & 35.00 & 7.84 & 27.16 & 77.60 \\
\hline 4 & 237.65 & 35.26 & 8.27 & 26.99 & 76.55 \\
\hline 5 & 260.59 & 35.51 & 8.67 & 26.84 & 75.59 \\
\hline 6 & 333.41 & 36.26 & 9.83 & 26.42 & 72.89 \\
\hline 7 & 705.25 & 50.47 & 15.48 & 34.99 & 69.33 \\
\hline
\end{tabular}

Fig. 15 below shows a non-linear variation of energy loss effectiveness with approach Froude number, which varied from 8,84 to 14,39. Energy loss effectiveness decrease with a decrease in approach Froude number. Chow and Chanson have presented a similar trend for the variation of relative energy loss with the Froude number method from their experimental studies [11]

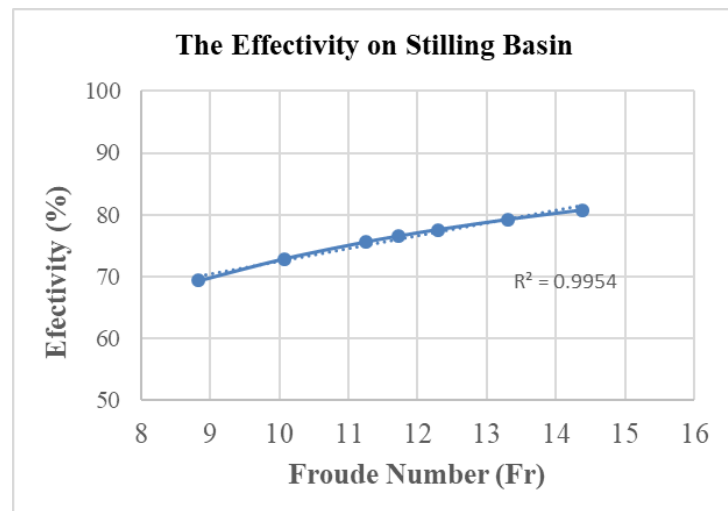

Fig.15. Variation of Relative Energy Loss of the Jump with Froude number

\section{CONCLUSION}

From the experimental data and analysis result, it can be concluded that the cross-flow was reduced by placing hexagonal baffle blocks on proper positions. The effectivity of stilling basin USBR Type 2 has happened with the abrupt rise installing on the downstream area because the lower of tail water depth condition at the downstream area. The modification on the model must be added to make the safe hydraulic performance condition.

\section{REFERENCES}

[1] Chanson,H. 2015. Energy Dissipation in Hydraulic Structures. Taylor \& Francis Group Publishing, London,UK.

[2] Awal A.S.M.A, Hosseini H. and Hossain M.Z., Strength, Modulus of Elasticity and Shrinkage Behaviour of Concrete Containing Waste Carpet Fiber, International Journal of GEOMATE, Vol. 9, Issue 17, 2015, pp. 14411446.

[3] De Vries, M.. Scaling Model Hydraulic, Netherland: IHE Published, 1997

[4] Triatmodjo, B., Hidrolika II (Hydraulics II), Yogyakarta: Beta Offset, 1996.

[5] Subramanya, K.. Flow in Open Channels, New Delhi: Tata McGraw-Hill Publishing Company Limited, 1996.

[6] Chow, V.T., Hidrolika Saluran Terbuka (Opened Channel Hydraulics), terjemahan E.V. Nensi Rosalina, Jakarta: Erlangga, 1997.

[7] Limantara, L., Priyantoro, D., Prasetyorini, L., and Darmawan, R., Design of Stilling Basin for Decreasing Back Water in The Dam Foot. International Journal of GEOMATE, Vol. 15, Issue 51, 2018, pp. 98-105.

[8] Chanson, Hubert. 1999. The Hydraulics of Open Channel Flow: Basic principles, sediment motion, hydraulic modelling, design 
of hydraulic structures. Elsevier's Science \& Technology Rights Department in Oxford, UK.

[9] United States Department of the Interior: Bureau of Reclamation. Design of Small Dams, Oxford \& IBH Publishing CO, New Delhi Bombay Calcutta. 1973.

[10]Hager, W.H. Energy Dissipators And Hydraulic Jump, Kluwer Academic Publishers, Dordrecht. 1992.
[11] Prasetyorini, L., Anwar, N., Wardoyo, W. 2018. The Effectiveness of USBR Type 3 Stilling Basin with Lower Tail Water Depth on The Way Apu Spillway Dam. Proceedings of the $21^{\text {st }}$ IAHR-APD Congress 2018, Yogyakarta, Indonesia, pp. 233-238.

Copyright (C Int. J. of GEOMATE. All rights reserved, including the making of copies unless permission is obtained from the copyright proprietors. 